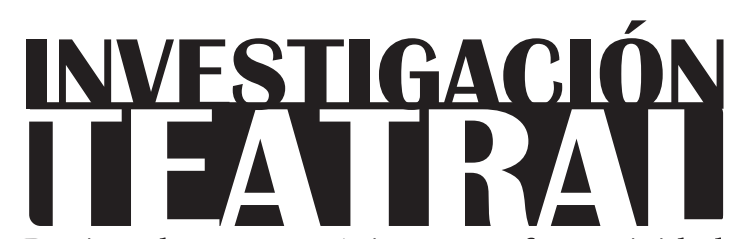

Revista de artes escénicas y performatividad

Vol. 12, Núm. 19

abril-septiembre 2021

Segunda época

ISSN impreso: $1665-8728$

ISSN electrónico: 2594-0953

Universidad Veracruzana

\title{
Documento:
}

\section{Dramaturgia pandémica: Dos obras}

\author{
Florencia A. Davidzon*
}

\footnotetext{
* Creadora independiente, Argentina. e-mail:fdavidzon@gmail.com
}

Recibido: 18 de diciembre de 2020

Aceptado: 04 de enero de 2021

Doi: $10.25009 /$ it.v12i19.2676 


\section{Dramaturgia pandémica: Dos obras}

\section{Florencia A. Davidzon}

N ació en Buenos Aires, en 1972. Es licenciada en Ciencia Política por la Universidad de Buenos Aires (1994) y Magister en Artes por Maine Media College (Rockport, 2016). Estudió creación literaria y guion en el Centro Internacional de Guionismo, Cine y Televisión (CigCiTe), México, y en UCla extensión, California. Se formó en actuación y escritura teatral en varios talleres con maestros como Julio Chávez, Carlos Gandolfo, Raúl Serrano, Ximena Escalante, Mauricio Kartun, Ariel Barchilon, Antonio de la Parra y Lautaro Vilo, entre otros.

Fue parte de la residencia de dramaturgia en C.A.S.A, Etla, Oaxaca (2017), con el proyecto de exploración de teatro musical fantástico "Cumbia Calea", y como guionista fue residente del Instituto Sonorense de Cultura/IMCine (2017), además de becaria del Talent Campus Guadalajara (2018), con el proyecto "Violeta", entre otros. Escribió dos novelas cortas, Violeta y Piedras de Cananea; la primera, de pronta publicación.

Asimismo, produce y dirige cine independiente desde 2006. Su largometraje documental Los Quijotes de la Marcha participó en varios festivales internacionales y ganó como mejor película en el festival de cine de Oregón en 2017. Su corto de ficción Navidad, realizado en 2014, participó en el Sunscreen Film Festival en Florida y en el Guanajuato Film Festival México; obtuvo menciones de mérito en BestShorts, en las categorías de Women Filmmakers y Latin/Hispanic, en 2015. 


\section{Nota introductoria}

Sentidos e Hipnopedias (o Hipnopómpicas) son dos obras cortas inéditas de la dramaturga y cineasta argentina-mexicana Florencia Davidzon, las cuales surgieron como parte del proyecto de creación colectiva "Palomazos", promovido por la Secretaría de Cultura y el Teatro Helénico, durante el año 2020, dentro del programa Contigo en la Distancia, como ayuda debido a la contingencia por Covid-19. Las versiones originales fueron editadas para ser grabadas y representadas en formato y duración acotada de teatro digital.

Las obras que publicamos aquí, con permiso de la dramaturga, son las versiones originales y completas. Son fruto de un inusual proceso de trabajo colaborativo mediado por la tecnología. Actores, músicos, coreógrafos, directores, productores y la dramaturga -que no se conocían ni se conocieron de manera vivencial, sino hasta el momento del rodaje de una sola pasada - trabajaron a distancia durante el confinamiento, intentando encontrar una expresión artística y colectiva al devastador momento histórico que tomó a todos por sorpresa y ha impactado radicalmente de diferentes formas las vidas de toda la población, así como a los habitantes de la Ciudad de México de una forma propia y singular. 


\section{Hipnopedia}

Por Florencia Davidzon

\section{Elenco}

J (Jorge Enrique Sánche Viñas)

So (Stephano Morales Bautista)

Sy (Stephanie Liset Molina Ríos)

E (Eréndira Alejandra Castorela Vázquez)

Dirección: Alejandra Chacón Cuéllar.

\section{Locación}

En un escenario vacío...

\section{Escena 1.}

Un baile en 4 tiempos $(A, B, C, D)$, una coreografía de imágenes muy coordinadas, breves y encadenadas...

Baile "Te vi": Cuerpos despreocupados salen desde las cuatro esquinas, empiezan a descubrirse en la distancia: "te veo", "me interesas", "me siento atraído"; hay coqueteo y seducción desde la distancia; son desconocidos, pero se despertó el interés "de encuentros" que son aún promesas: miradas, acercamientos medidos, primeras palabras...

Baile "Me interesas, te busco": Los cuerpos comienzan la seducción, son flirteos y acechos a partir de provocaciones cuidadosas, medidas, sugeridas, y avanzando con ciertos reparos...

Baile "Tiene que ser hoy, dame el sí": Ahora decididos, avanzan envalentonados para la acción y la conquista; se deciden a ir... desde las esquinas van a tomar carrera para sorprender a su futura pareja... (uno tiene una flor; otro, un libro; otro, una taza de café; otro, unos boletos para un espectáculo...).

Baile "Invitación seamos uno": Los actores corren hacia el centro con los brazos abiertos para abrazarse, o con su boca en pico lista para besarse, pero se detienen repentinamente a dos metros de distancia, entrando en "shock" (mientras todo se torna 
ROJO). Se escucha el sonido: “AAlerta sanitaria, quédate en casa, cuídate, y cuídanos!". Los actores "impactados" acatan y se alejan.

\section{Escena 2. Insomnio (Vigilia)}

Cuatro cuerpos que empiezan a perder su confort. Están en lucha con su propia inquietud e intranquilidad. En estado de alerta, se revuelcan en su espacio, cubiertos de sábanas y/o cobijas; luego, en sus movimientos, estas los asfixian y se ponen más impacientes... Ellos murmuran o hablan en volúmenes disonantes... Están en fila de izquierda a derecha, uno junto al otro de frente al público como en cuatro recámaras distintas.

E: Es el fin. (Intenta dormirse) Siento a la muerte...

P: Armonía, armonía... Tranquila, ¿dónde esta mi gata? Ven... (La llama con el brazo).

So: Te dije, relax... ¡Duérmete ya! Negro, veo todo negro... ¿Estoy respirando bien? Creo me duele la garganta...

J: Ya duérmete, cabrón... ¿Y si estreno ahorita mis acuarelas? No, no, los ojos piden descanso...

Sy: (Suspira, se zafa de las sábanas) Basta, basta de pensar... (Se pone a hacer una meditación sentada).

J: Respetar las horas de sueño... ¿No has oído? Me duelen las pantorrillas; seguro me lastimé las rodillas, me excedí con tanta bici... Chin... Ya tengo hambre otra vez...

E: Ya no tengo ni hambre... Mejor me prendo un cigarrillo; no, no, mejor no... Mejor checo otra vez si cerré bien la puerta...

J: (Mira por la ventana... cuando sus dos voces internas conversan.) ¿Qué haces? Miro las estrellas; al menos déjame tantito mirar las estrellas...

Sy: Vida...Vida...

\section{Escena 3. Estado hipnagógico (entre la vigilia y el sueño)}

Cuatro cuerpos más rígidos se empiezan a entregar al cansancio obligándose a cubrir sus ojos con tapaojos, o sus propias manos... cada uno, en posiciones singulares que fueron encontrado se entregan al sueño... deliran... fantasean... conjeturan...

J: Mándale un mensaje... 
P: Invítalo a una videoconferencia....

E: Yo pensaba que iríamos a caminar por el Ajusco, tal vez no... ¿Vendrás? ¿Nos veremos?

So: No hay dinero, no puedo invitarte a nada... Tengo que seguir mi estricta lista de compras...

E: Me siento sola, estoy sola... Mi abuela muerta me dice que todo bien, pero no le creo...

Sy: (Abre un ojo, mira su cel). ¿Qué posteó?, ¿qué día es? Todos los días parecen iguales...

J: Mándale un mensaje...

P: Invítalo a una videoconferencia...

\section{Escena 4. Sueño-apnea (parálisis del sueño, respiración entrecortada, suspendidas, pesadillas)}

\section{Los cuatro cuerpos están "más rígidos”... ahora abrazados a sus almohadas...}

J: Solo, solo... solo... No hay nadie... Hasta mi roomie me dejó... (respiración entrecortada). El futuro me visita, tiene un dedo señalador. Es tu culpa, es tu culpa, grita: "te equivocaste, ahora paga, paga”...

P: Es tu culpa, no desinfectaste bien... Se coló el intruso, lo dejaste entrar... Está aquí, ¿lo ves? En cualquier momento ataca... 14 días vive en el refri, no lavaste bien, no lavaste la fruta...

E: ...Botones, accesos, passwords; todos son botones, pantallas, estoy sola, sola... Nadie te va a tocar nunca más... Llegué a la oficina, no me puse los guantes; mi jefe me va a echar. ¿Por qué saludé con la mano sin guantes?, me reclama la de recursos humanos.

So: La casa se inunda... No sé nadar... Se llena de agua... ¿Dónde estoy? ¿Quién soy? No hemos reciclado lo suficiente; me invade la basura y toda nuestra mierda... Hemos abusado de los recursos... ¡A Abusador! ¡Abusador! Me dice mi voz, mientras el agua se vuelve muchos empaques de enormes papitas, de refrescos, de plásticos, y más mugre... Me ahogo...

Sy: $\mathrm{Y}$ en un segundo voy ganando años. Mi cuerpo como manzana podrida se transforma de inmediato y se hace vieja. Mi alma se aleja de mí. Ven, ven, regresa. ¿Me estoy muriendo? No, acá sigo, me alivio. Estoy alterada y luego me calmo hasta que caigo. Cargo un peso enorme en la espalda, caigo. Me chupa el precipicio, y caigo con un cuchillo en las manos... ¿Para qué quiero un cuchillo en las manos? 


\section{Escena 5. Estado hipnopómpicas (alucinaciones previas al despertar)}

Los cuatro cuerpos abrazados a diferentes objetos: una guitarra, unos zapatos de baile, libros, cuadernos y plumas, películas, fotos de amigos/familiares, tubo de teléfono antiguo -no digital-, carteles de palabras, etcétera.

J: No puedo concentrarme, me duele la espalda, pero de pronto me tocas la mejilla... me gusta...

P: Nos rozamos las piernas....

E: Me sonríes... Huelo la tierra mojada del parque... Me sonríes otra vez, empiezo a cantar...

So: Siento tu abrazo, tu corazón salir de su cuerpo y que entra en el mío...

Sy: Es amor. Hay amor no lo dudo. Estoy frente a una madre en el Centro Histórico con sus niños en brazo; le da el pecho y me emociono, se me cae una lágrima...

E: Soy positiva, pero (tararea)... "Cuando paso por tu casa... Me da ganas de llorar... De ver las puertas abiertas y yo sin poder entrar... Sin esperanza ninguna... Llorando me agarra el día....

(Todos los actores despiertan, golpean puertas imaginarias queriendo salir... pero siguen encerrados).

\section{Escena 6. (Se repite escena 1 pero con un giro)}

Baile "Invitación seamos uno": Los actores corren hacia el centro con los brazos abiertos para abrazarse, o con el pico de la boca listo para besarse, pero se detienen repentinamente a dos metros de distancia, entrando en "shock", mientras todo se torna VERDE. Se oye el sonido: "AAlerta sanitaria: recuerda que el objetivo es no contagiar ni contagiarse!". Los actores “impactados” no saben qué hacer. Dudan. Están paralizados. ¿Dónde pongo mis manos? ¿Qué hago? Luego (¿Algunos se ponen tapabocas?) al unísono y con precaución, avanzan... con cuerpos sobrevivientes / traumados / desencajados que han pasado por los efectos de la tortura... pero avanzan, avanzan.

\section{Negros.}




\section{Sentidos}

Por Florencia Davidzon

\section{Elenco}

A- Táctil (Aleyda Gallardo)

P-Auditivo (Patricia Caña)

S- Gustativo (Selene De Silva)

K- Visual (Karina Castro)

En el escenario están A, P, S, K.

(Los cuerpos danzan movidos por su sentido mayor... con disfrute o martirio, componen algo figurativo entre las 4 a distancia. Los cuerpos pelean por no quedar detrás de unas vallas que finalmente se les imponen y fungen como un podio o marco de cuadro o ventana para enmarcar a la personaja que monologa... ellas van tomando lugares y hablando detrás de esa valla, reja...)

K: Como esto no se puede ver, o no se deja ver... al comienzo sentí calma...

P: Voy a enloquecer... Se los advierto...

A: No toco, no beso, siento... No, no siento.

S: Al fin una pausa; vuelvo a notar mi pulso, mi energía, lo saboreo. Finalmente, respiro, sonrío. Hoy puedo ser de veras. ¿Tú ya sabes que estás vivo, que estás viva?

A: Soy silencio. Un largo silencio. Tengo miedo. No, no es miedo; tal vez es fobia. Me paralizo. Lloro. Un poco, solo un poco. Yo acato. Luego, me rebelo, no me baño.

K: ¿Qué es lo que quieren ver? ¿Para qué verlo todo? Ver para creer; no, no hay que ver.

P: No quiero morir. ¿Tal vez todo sea mentira, no crees?

A: De pronto no respiro bien. Trago pánico. Me huelo la axila, me inunda mi nauseabundo sudor, me calmo llena de alegría. Inhalo.

P: Los silbidos del camotero ya no son mi martirio... Me he intoxicado de alarmas de autos, de caños de escapes de motos, de sirenas de ambulancias, de patrullas de polis (hace los sonidos ensordecedores, alocados)... Soñaba con volar, pero con mi tímpano a flor de piel ya no sé...

K: Temo... Temo por mi niño; él es tan frágil. Sus ojos sin filtros, bien pegado a la pantalla. A veces, me enojo conmigo por pedirle que apague de mala manera, que ya no vea; lo asusto, le digo que se va a quedar ciego... Me siento culpable... ¿Hace falta ver, ser 
testigos de nuestra propia destrucción? ¿Hace algún sentido mirar nuestro propio accidente como humanidad?

P: Un ambulante de fruta que pasa a diario con su megáfono de anuncio grabado. No le importa taladrar mi concentración. Él avanza y ataca mi imaginación, ya no puedo volar...

S: Tomo una fruta. La siento, la muerdo, la destrozo, la salivo, la siento... Siento rico... sabe dulce. Amo este encierro, tener este paréntesis, este refugio. Solo odio tanto silencio...

P: La voz del vendedor de gas me perfora como una bomba al último bastión de mi... Pido silencio. ¿Es tanto pedir? Silencio... Grito (grita). Un grito agudo, largo, majestuoso, pero no me calma ni perturba a nadie...

K: Sí miento, pero si puedo esconderle mi cansancio, mi ansiedad y mi depresión, también puedo mentirle, puedo censurarle el acceso a tanta imagen. ¿Me lo reclamará cuando cumpla 15 o 20 ?

A: Te mendigo amor, pero luego no me animo. Soy silencio, un largo silencio.

P: Mis vecinos se han descontrolado; rugen como animales enjaulados. Creo que nada puede ser peor cuando una maza cae sobre mi techo, los vecinos del tercero D empezaron a hacer reparaciones...

K: Golpea, golpea, le pido. Quiero salvarlo, lo obligo a que juegue, a lo que sea con tal de que se aleje de las noticias. Patea la pelota, le digo; rompe toda la casa, corre, corre, sí en círculos, usa tus ojos para atinarle, enfoca entre las dos sillas...

S: Tengo actividades para alimentar a mi paladar y calmar mis antojos; no quiero sentir hambre y se cuele mi "inutilidad", que nadie vea mi vida como un platillo despojado de todo artificio. Que nadie sospeche de mi "improductividad". Que nadie se atreva a señalar mi gula, mi ocio...

A: Tocas. Entras. Te acercas, te temo, me alejo. Yo acato, te digo. Te anulo. Me torturo de deseo. Me pregunto, ¿me domesticaron? ¿Me atraparon?

P: Las marimbas invaden la cuadra, me revuelcan como una ola del Pacífico embravecido... El timbre para solicitar mi coperacha enciende los ladridos de mi perro... Me rio (risa de alto volumen) retumba en mis cuatro paredes que me hacen temblar de espanto.

A: Imagino tus manos mojadas, tu cachete tibio, lo pegajoso de un cuello... El pecho de mi mamá... La humedad de un brazo ausente. Me enrosco en mi cama. Temo morir, temo vivir...

K: Anochece otra vez. Invito a mi hijo a contar cuántos pájaros se acercan a nuestro balcón... Para que mire, que vea todo lo que hay qué ver; que observe y recuerde esta imagen de nuestra ciudad. 
INVESTIGACIÓNTEATRAL

Revista de artes escénicas y performatividad

Vol. 12, Núm. 19

abril-septiembre 2021
Dramaturgia pandémica: Dos obras

Florencia A. Davidzon

P: Silencio. Solo pido silencio. Ruidos de cascadas, de viento y de grillos... Me pregunto: ¿cuándo alguien en este encierro nos dará susurros, palabras suaves, cantos de cuna me eleven, y nos eleven a todos?

S: Que los invada la calma. Me siento plena, no necesitamos nada. Podemos estar a gusto. Tener gozo y decidirnos a disfrutar del delicioso manjar de nuestros latidos.

A: Me abrazo, me toco, me siento y, por fin, me duermo.

\section{Telón.}

